Physical Disabilities: Education and Related Services, 2016, 35(2), 23-48. doi: $10.14434 /$ pders.v35i2.22171

(C) Division for Physical, Health and Multiple Disabilities

PDERS

ISSN: 2372-451X

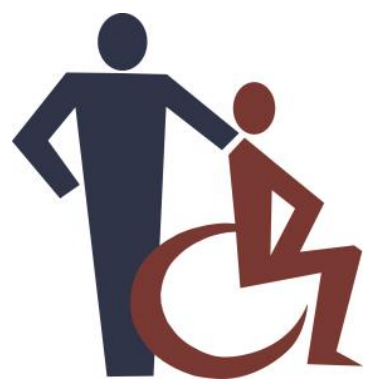

http://scholarworks.iu.edu/journals/index.php/pders/index

Article

\title{
A CULTURALLY AND LINGUISTICALLY RESPONSIVE FRAMEWORK FOR IMPROVING ACADEMIC AND POSTSECONDARY OUTCOMES OF STUDENTS WITH MODERATE OR SEVERE INTELLECTUAL DISABILITY
}

\author{
Christopher J. Rivera \\ East Carolina University \\ Bree A. Jimenez \\ University of North Carolina at Greensboro \\ Joshua N. Baker \\ University of Nevada, Las Vegas \\ Tracy Spies \\ University of Nevada, Las Vegas \\ Pamela J. Mims \\ East Tennessee State University \\ Ginevra Courtade \\ University of Louisville
}

\begin{abstract}
The needs of culturally and linguistically diverse (CLD) students with moderate or severe intellectual disability (ID) are quite unique and complex. CLD students with moderate or severe ID face many of the same issues as their non-disabled CLD peers; however, due to the nature of their disability this may lead to even less access to the general curriculum, appropriate services, materials, and meaningful collaboration between families and educators. The purpose of this article is to provide a culturally responsive framework for facilitating academic instruction for CLD students with moderate or severe ID that also includes appropriate supports in an effort to increase access to postsecondary outcomes for this population. Suggestions for accessing the general curriculum and a discussion about increasing parental involvement and accessing appropriate adult agencies to further enhance these outcomes are provided.
\end{abstract}

Keywords: intellectual disability; culturally and linguistically diverse; transition; general curriculum access 


\section{Introduction}

Over the last several years there has been an increase in the number of culturally and linguistically diverse students across the United States. Culturally and linguistically diverse (CLD) refers to the increasing population of students who have diverse cultural and linguistic backgrounds differing from dominant groups (Herrera \& Murry, 2011). To further clarify, this term is inclusive of individuals from diverse cultural and socio-economic backgrounds and whose primary home language is not English. According to Gonzalez, Pagan, Wendell, and Love (2011), the term is most commonly used to describe students who are non-English proficient, limited-English proficient, or English language learners (ELL). The term CLD is preferred over other terms because we view cultural and linguistic diversity as an asset and it allows for recognition that the needs of these students go beyond simply acquiring the English language.

According to the U.S. Department of Education (2015) almost 10\% (4.5 million) of the total student population speaks a language other than English in the home. Research has long demonstrated the difficulties that CLD students encounter. For instance, CLD students tend to score lower on academic achievement tests, are more likely to face disproportionate representation within special education, and may have poor access to quality educators (Fry, 2008; Peske \& Haycock, 2006; Sullivan, 2011). These issues negatively influence high school graduation rates, which in turn influence the number of students who are prepared and have the means to enter four-year college programs (Calaff, 2008). In 2013-2014, CLD students were reported as having a graduation rate near $60 \%$, while students with disabilities had a rate of $63 \%$; this in comparison to the national graduation rate of $82.3 \%$ (National Center for Education Statistics, 2015).

\section{CLD Students with Moderate or Severe Intellectual Disability}

The current statistics available for typically developing CLD students demonstrate the continued need to support and determine ways to better facilitate instruction that is sound in pedagogy. Upon closer examination of this population we find that although there is literature to support best practices for academic and language development (e.g., Calderon, 2007; Cline \& Necochea, 2003; Krashen, 1982; Linan-Thompson \& Vaughn, 2007), researchers need to continue investigating ways to assist practitioners who educate CLD students who are simultaneously receiving special education and English language services (Park, Magee, Martinez, Willner, \& Paul, 2016). There is a lack of regulatory guidance as policies and definitions of English language proficiency differ from state to state (U.S. Department of Education, 2015), which may attribute to difficulties practitioners face when determining appropriate services for CLD students with special needs. Adding to this complexity is the severity of one's disability. Thus far, the statistical data provided is primarily in reference to CLD students and CLD students with high incidence disabilities (e.g., learning disabilities). Those with moderate or severe intellectual disability (ID) seem to be left out of the equation. For instance, IDEA statistical data reports on the number of students with disabilities, lists the number of students within disability categories, and provides the number of limited English proficient students served by IDEA Part B. Yet, there are no data distinguishing which of these students are both limited English proficient and have a moderate or severe intellectual disability (IDEA Section 618 Data Products: Static Tables, 2016). If school systems still struggle in determining how to serve CLD students with high 
incidence disabilities then the question must be asked: How do we best serve CLD students with low incidence disabilities (i.e., moderate or severe ID)?

CLD students with moderate or severe ID have faced many of the same issues as their nondisabled CLD peers (e.g., academic difficulties, postsecondary transition opportunities, language barriers); however, due to the nature of their disability, access to the general curriculum, appropriate services (e.g., translators), appropriate materials, and meaningful collaboration between families and educators may be more problematic (Kim \& Morningstar, 2005; Mueller, Milian, \& Lopez, 2009; Mueller, Singer, \& Carranza, 2006; Spooner, Rivera, Browder, Baker, \& Salas, 2009). What is equally worrisome is the lack of proper training faced by educators of CLD students with moderate or severe ID. Mueller et al. (2006) noted that educational guidelines for students within this population, simply put, were uncharted. In a national survey that included a combination of 375 special educators, related service professionals, and inclusion specialists, Mueller et al. (2006) evaluated respondents' beliefs on several facets of educating CLD students with moderate or severe ID. More specifically, the researchers examined respondents' beliefs on second language acquisition, language of instructional practices, resources available, instructional satisfaction, and thoughts on parental participation in determining language of instruction. Results from the survey found that $37 \%$ of respondents were trained to work with this specific population. Ninety-two percent reported that they had either no second language ability or could engage in only a brief conversation in a second language. Over $80 \%$ of those surveyed taught both expressive and receptive language skills in English although their students were English language learners. About half of the respondents did not have access to materials in a second language, disclosed that CLD families were not consulted about the language of instruction that should be used, and provided some primary language support to their students. Of this group, almost $40 \%$ reported that they were dissatisfied with the instruction provided to their students. This is not uncommon as Paneque and Barbetta (2006) found that teachers typically indicated low levels of self-efficacy in making academic decisions for similar students, and with good reason. According to Park et al. (2016), there are insufficient guidelines for selecting proper alternate assessments and accommodations for CLD students with disabilities.

\section{Improving Quality of Life}

All students with disabilities are entitled to a free and appropriate public education. Determining what is appropriate for CLD students with moderate or severe ID is difficult given the little guidance that does exist (Mueller et al., 2006). Denying appropriate services and properly implementing best practices for academics and functional performance can not only impact current school performance but also can have ramifications extending to post school outcomes. Oftentimes, postsecondary transition options that lead to employment are limited for students with disabilities. The latest data available from the U.S. Bureau of Labor Statistics (BLS, 2013) reported that individuals with disabilities are employed at rates nearly half that of individuals without disabilities. In fact, research shows that only $58 \%$ of people with disabilities have fulltime employment after completing high school (Newman, Wagner, Cameto, \& Knokey, 2009). In addition, for individuals with ID, employment outcomes are some of the lowest reported, even when compared to other individuals with disabilities (Migliore \& Butterworth, 2008; Siperstein, Parker, \& Drascher, 2013). If a student has an ID and is also CLD, employment rates are even lower (Trainor, Murray, \& Kim, 2014). 
Turnbull, Turnbull, Wehmeyer, and Park (2003) discussed that legislation reform (i.e., IDEA, 1997) brought about goals for special education that still exist today. These goals were to provide equal opportunities to students with disabilities, allow them full participation in the general curriculum, teach them to be independent, and teach them to be self-sufficient. To do this, and improve the quality of life for CLD students with moderate or severe ID, researchers and practitioners need to identify methods to best provide access to the general curriculum; providing realistic strategies that educators can apply in their classrooms immediately. Moreover, researchers and practitioners need to devise culturally responsive strategies that will improve post school transitions; considering that postsecondary transition opportunities are now becoming more readily available to individuals with ID (Grigal, Hart, \& Weir, 2013).

\section{Purpose}

The purpose of this article is to provide a culturally responsive framework for facilitating academic instruction and to yield improved transition supports for CLD students with moderate or severe ID. Although there is a lack of specific research focused on this population, the proposed framework considers the evidence-based research from CLD and ID fields. First, a review of current instructional models will be discussed, followed by the proposed culturally responsive framework and its eight variables derived from best practices, and finally a discussion of how this framework can create byproducts that can enhance access to and preparation for postsecondary opportunities.

\section{Establishing an Academic Culturally Responsive Framework}

Best practices for academic instruction indicate that: (a) culturally responsive techniques, (b) explicit and systematic instruction, and (c) native language support, are essential in developing skills and knowledge for CLD students with disabilities (e.g., August \& Shanahan, 2006; Gersten \& Baker, 2000; Spooner et al., 2009; Rivera, Wood, \& Spooner, 2012). Currently there seems to be little guidance on what methods may work best for this group of students and how educators may incorporate various strategies to enhance student outcomes. Although the literature provides a plethora of strategies and models that can be adapted to meet the individual needs of such students, there are a lack of guidelines on which strategies can be combined to enhance student outcomes; specifically addressing students with CLD who have moderate or severe ID.

\section{Reviewing Current Models of Instruction}

Specifically Designed Academic Instruction in English (SDAIE; Sobul, 1995), a variant of sheltered instruction that has been shown to increase academic content taught, in addition to increasing second language acquisition for CLD students (Crawford, 2005), focuses on creating a classroom atmosphere that to some degree shelters CLD students from English linguistic demands. Lessons are created to focus on content being taught and incorporate a student's primary language as a way to build comprehension in a second language. As a part of the SDAIE model, the connection between second language acquisition and academic content being taught is critical. According to Ovando and Combs (2012), "students acquire second-language skills when these skills are taught in meaningful context and are not isolated from subject matter" (p. 38). 
From this instructional model, Cline and Necochea (2003) argued that SDAIE would need to evolve to meet the growing demands of CLD students entering mainstream classrooms and that many SDAIE strategies would need to be added to an educator's repertoire. Noting that their framework was not a one size fits all, Cline and Necochea provided the following conceptual model to improve academic outcomes for CLD students in general education settings: (a) connecting to previous learning, (b) using visuals and manipulatives, (c) providing low risk and safe environments, (d) providing multiple access points, (e) creating cooperative and interactive instruction, (f) chunking and webbing, ( $g$ ) being respectful of the learner, and (h) using primary language support.

The components provided by Cline and Necochea (2003) are invaluable; yet Sanford, Brown, and Turner (2012) noted that SDAIE was not designed for those students who have significant academic needs or disabilities. In response, Sanford et al. proposed the PLUSS framework, which consists of five components (Pre-teaching critical vocabulary, Language modeling and opportunities to use academic language, Using visuals and graphic organizers, Systematic and explicit instruction, Strategic use of native language) that include many of the same strategies used in SDAIE. Despite this overlap, PLUSS is designed to aid struggling CLD students across various Response to Intervention (RTI) tiers; offering a continuum of supports that seek to supplement current educational curricula. Whereas SDAIE provides assistance in core curriculum, the PLUSS model acknowledges that CLD students can struggle beyond core content and may need further assistance. Its flexibility to be used in conjunction with other interventions is what makes the PLUSS model unique. Both models still fail to meet the needs of CLD students with moderate or severe ID who are beyond levels of support within the RTI model, receive more restrictive special education services (e.g., self-contained settings), and have additional needs unlike their non-disabled CLD counterparts.

\section{Combining What We Know}

The theoretical underpinnings and strategies of both SDAIE and PLUSS incorporate research based strategies that are beneficial to an array of CLD students (Calderon, 2007; LinanThompson \& Vaughn, 2007); however, the needs of CLD students with moderate or severe ID are complex and require additional supports (e.g., the use of technology such as a voice output device, acquiring daily living skills to become more independent). This is especially true considering general curriculum access and the growth of postsecondary options. Downing and MacFarland (2010) have coined the phrase A New Way of Thinking; rightfully interpreted as special education moving away from taking care of those with exceptionalities to now expecting those with exceptionalities to learn and make advancements in their lives and communities. The question is no longer "whether students can learn, but how much they can learn, and with what types of instruction and support" (p. 2).

For that reason, we have proposed a culturally responsive framework to further facilitate access to the general curriculum for CLD students with moderate or severe ID in an effort to also improve access to postsecondary opportunities. This framework builds upon previous instructional models (Cline \& Necochea, 2003; Sanford et al., 2012) and extends these works to address the specific support needs of CLD students with moderate or severe ID. 
Also organized into eight variables, our framework (see Figure 1) is designed to respond to the diverse needs of this population through: (a) Universal Design for Learning, (b) establishment of a safe learning environment, (c) systematic and explicit instruction, (d) the integration of culture, (e) primary language support, (f) multiple opportunities to respond, (g) technology, and (h) selfdetermination. These variables should be treated equally; hence one variable is not better or needed more than the other. When triangulated, these variables can provide the necessary scaffolding and supports to CLD students with moderate or severe ID in helping prepare them for positive and productive post-school outcomes. The framework's variables are described below.

Universal design for learning (UDL). In 1998, the Center of Applied Special Technology (CAST) introduced the principles of universal design for learning to the Council for Exceptional Children (http://cast.org/about/timeline/index.html\#1998). These principles originated from the concept of universal accessibility from the field of architecture and were inspired by the Civil and Disability Rights movement (i.e., Architectural Barriers Act of 1968) as a means of providing access to individuals with disabilities to buildings. Since 2000, the theoretical importance of UDL has been discussed in the development of classroom instructional environments for students with disabilities (Meyer \& Rose, 2000). CAST's guidelines of UDL principles state that in order to enhance learning environments, multiple means of (a) representation, (b) expression, and (c) engagement must be provided and planned "prior" to instruction (CAST, 2011). UDL principles should assist and promote the collaboration of educational teams (e.g., special education, general education, ESL, and bilingual teachers) to design environments and curricula that meet the needs of all students, including CLD students with moderate or severe ID. The effect of knowledge and training in UDL has shown promising results with both special education and general education teachers (Courey, Tappe, Siker, \& LePage, 2013; Spooner, Baker, Harris, Ahlgrim-Delzell, \& Browder, 2007). For instance, an empirical study by Coyne, Pisha, Dalton, Zeph, and Smith (2012) investigated a technologybased UDL approach to literacy instruction (i.e., phonemic awareness, phonics, fluency, vocabulary, and comprehension) with primary aged children. The results of this study found that students with ID were able to participate in literacy activities/skills when additional scaffolds (e.g., UDL principles) were designed for each individual student's needs prior to instruction.

For CLD students with limited English proficiency, Lopes-Murphy (2012) indicated that UDL principles can be embedded into lessons using a multisensory approach and, by strategically creating access to English content (i.e., engaging students with the use of their primary language to access this content), it is possible for students to increase content learned while acquiring the English language. Although the research on UDL is limited for CLD students, its theoretical importance is significant when considering the proposed framework. The benefit of UDL is that educators plan instruction that will be inclusive of all students prior to implementation of that instruction. Considering the influx of CLD students in mainstream classrooms (U.S. Department of Education, 2015; National Center for Education Statistics, 2016), the incorporation of UDL principles is beneficial to all instructors as it obligates them to critically evaluate lesson development to ensure multiple access points for all students, which is particularly needed for CLD students with moderate or severe ID. 


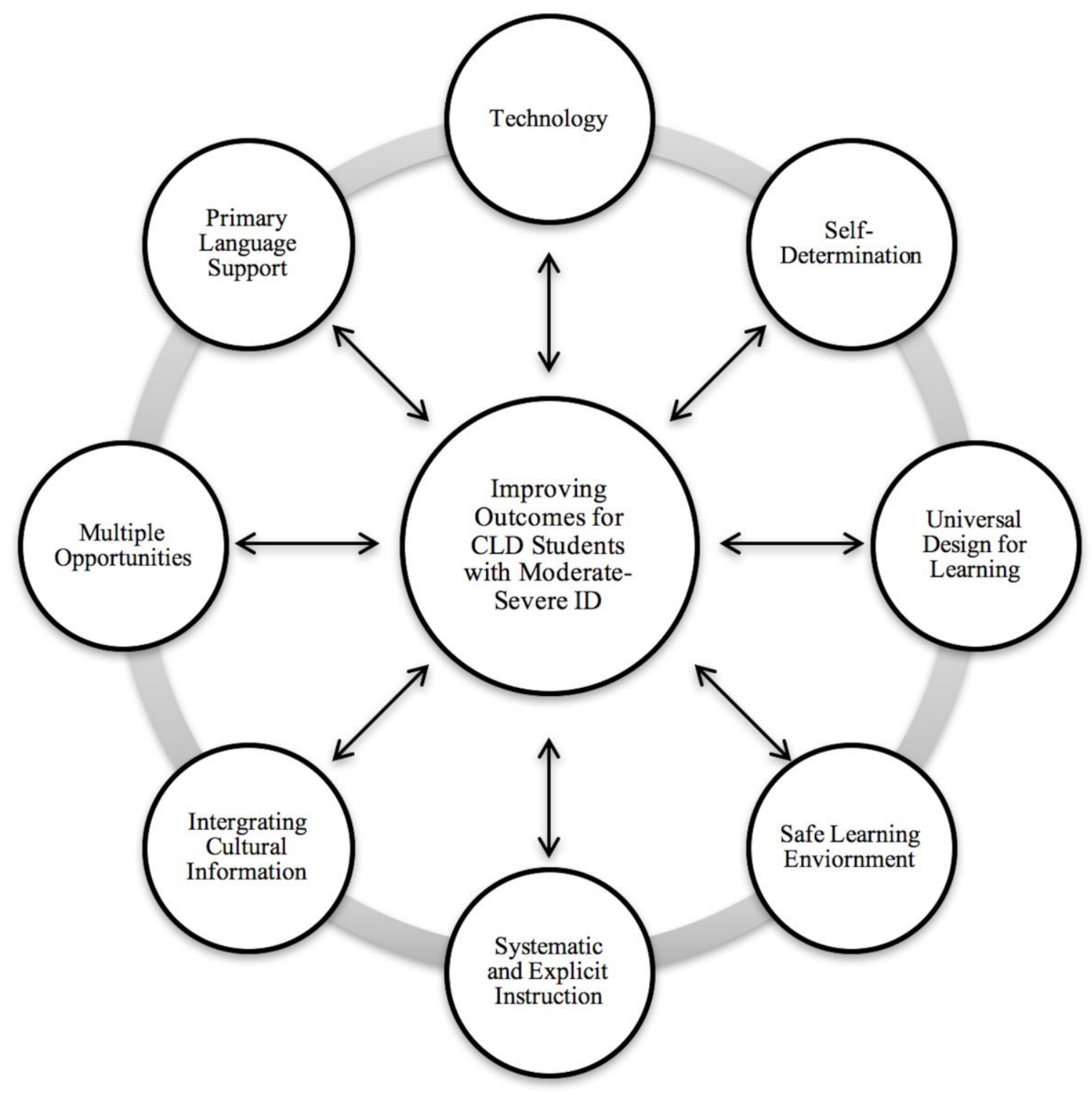

Figure 1. Academic culturally responsive framework for students with moderate or severe intellectual disability. 
Safe learning environment. Throughout history, individuals with ID have been maltreated, isolated, segregated, and discriminated against (Griffiths et al., 2003; HornerJohnson \& Drum, 2006; Ward \& Stewart, 2008). A safe and stress free environment in which students are respected is essential for all students, including those who are CLD (Schinke-Llano \& Vicars, 1993). Components of safe educational environments are those that (a) promote dignity, (b) allow for self-advocacy and self-determination, and (c) offer programs that are inclusive (i.e., allow access to the same settings and activities in which all students participate; Pennington, Courtade, Ault, \& Delano, 2016).

Teachers can create safe, comfortable environments for CLD students with moderate or severe ID by including family pictures, familiar children's literature, and by demonstrating respect for a student's primary language (e.g., by labeling items in the student's first language). Moreover, safe environments reflect the diversity of the learning community by representing the unique work and ideas of all students. Teachers should remember to be introspective and develop their own cultural competence and an ability to recognize and act on cultural orientations to better assist diverse students to become more self-determined and advocate for themselves (see Self-determination section for additional suggestions).

A safe environment is one in which CLD students feel free to take risks because the environment is characterized by low anxiety among students and fosters motivation and self-confidence (Cline \& Necochea, 2003). Learned helplessness can be a crutch for students with moderate or severe ID, therefore these students should be given opportunities to participate and respond in ways that continue to build their confidence and emphasize their strengths. They should be given a voice and be allowed to provide input in what they learn and aspire to be, especially when transitioning to young adulthood. Educators within these environments should be receptive to not only concepts such as person centered planning (Miner \& Bates, 1997) but also sensitive to the desires of the family unit, taking their thoughts and desires for education and postsecondary goals into consideration (Callicott, 2003).

Systematic and explicit instruction. Cartledge and Kourea (2008) suggested that instructional strategies go beyond a one-size fits all model. Considering how diverse CLD students with moderate or severe ID are, it is important to incorporate instructional strategies that are multifaceted. The use of systematic instruction is evidence-based and has been shown to be highly beneficial for students with moderate or severe ID (Browder, Wood, Thompson, \& Ribuffo, 2014). This form of explicit instruction is rooted within applied behavioral analysis and attributed to B. F. Skinner's behavior theory (Skinner, 1963). Systematic instruction assures a consistent pattern of instructional trials that incorporate an antecedent, behavior, and consequence. The consistency of these instructional trials may be implemented by various individuals and should include operationalized procedures (e.g., specific prompts, schedule for fading prompts, feedback for correct and incorrect responses). Similarly, systematic and explicit instruction is also critical for CLD students with moderate or severe ID (Spooner et al., 2009). Although we should not limit ourselves to behavioral forms of instruction (Banks, Sapp, \& Obiakor, 
2013), considering the diversity among students, research has demonstrated the benefits of systematic and explicit instruction for a wide range of students (e.g., Haager \& Klingner, 2005; Klingner \& Vaughn, 2000). Carefully sequenced, explicit instruction provides scaffolding opportunities not only to build instructional content, but systematic opportunities to develop language (Lopes-Murphy, 2012), which are essential considering the needs of CLD students with moderate or severe ID (e.g., Spooner et al. 2009).

For students with moderate or severe ID, generalizing newly learned skills can be very difficult and thus problematic if these skills cannot be generalized in natural environments. If students with moderate or severe ID are going to be independent and successful out of the classroom, they need to be able to apply skills learned in the classroom to real-life settings. Multiple exemplar training, a strategy also embedded in behavioral theory, is a method in which multiple examples of a stimulus are systematically presented to an individual to expand his/her repertoire of that specific stimulus (Cooper, Heron, \& Heward, 2007). For example, when teaching a student the concept of an automobile, an instructor may present various pictures of automobiles in various shapes, sizes, and colors. Instruction that is inclusive of multiple examples can lead to improved generalization outcomes (Cooper et al.; Greer, Chavez-Brown, Nirgudkar, Stolfi, \& Rivera-Valdes, 2005) and facilitate learning and maintenance of English vocabulary (Restrepo, Morgan, \& Thompson, 2013).

According to Engelmann and Carnine (1991), for instruction to be effective it must be clear, predictable, and allow students to generalize what has been taught. Educators can do this by modeling examples and non-examples when teaching new concepts. In order for students to understand a concept, it is imperative that they understand not only what it is, but also what it is not. For instance, Hicks, Bethune, Wood, Cooke, and Mims (2011), taught prepositional phrases to students with ID using direct instruction along with examples and non-examples. Results demonstrated that all students were able to use the prepositions in the correct context after training (e.g., this is over, this is not over). All students can benefit from the use of multiple examples in a lesson to solidify the meanings of concepts; however, CLD students with moderate or severe ID may need an increased emphasis and focus on including multiple examples to ensure that concepts learned in the classroom can be generalized in varying contexts. Therefore, when taking into account UDL and planning instruction ahead of time, educators should incorporate strategies from these theoretical foundations and embed them within the learning environment to support all learners.

Integrating cultural information. Taking time to understand a student's cultural heritage/socio-cultural background can help educators determine what skills can be linked to class assignments that aid in understanding new materials. Moll, Amanti, Neff, and González (1992) acknowledged that a student's funds of knowledge, cultural household knowledge needed for functional well-being, could be used as a rich source of cognitive wealth. Educators should tap into a student's experiences (i.e., prior knowledge) and create lessons that are culturally responsive, thereby decreasing anxiety and making learning less demanding (Krashen, 1982). For example, when teaching 
emergent literacy skills to a Latina student with autism, Spooner et al. (2009) selected cultural and contextual books with the help of an adult who knew the student well and shared a similar cultural background/upbringing. By selecting age-appropriate, culturally contextual literature, the student was able to participate in shared stories to which she could relate. Arguably, the student's previous experiences in relation to the content of the stories may have increased motivation levels, language, and/or the entire literacy experience. Since many CLD students, in general, do understand and comprehend concepts better than they can communicate, it is important that prior instruction provide a bridge between what is known (e.g., culturally contextual experiences) and what is unknown (e.g., language and new content; Haneda \& Wells, 2012). These funds of knowledge can be useful when trying to determine how to construct new access points to general curriculum standards and making connections to newly acquired information.

The use of funds of knowledge, based on the family unit, is also of importance to how families view transitioning to college or other postsecondary opportunities. Rios-Aguilar and Kiyama (2012) acknowledged that college preparation can often be influenced by socioeconomic status and race, but encourage practitioners to evaluate how a family's funds of knowledge may impact college preparation among CLD students, specifically Latinos. Although the work of Rios-Aguilar and Kiyama focused on Latino families, what can be inferred from their work is that CLD families often develop knowledge based on their own experiences and those of extended family members. Furthermore, these diverse families are often more willing to assist in planning for their child's postsecondary transitions and do have knowledge on how to prepare for such plans but are often undermined by others' perceptions based on their ethnicity or socioeconomic status. If educators can overlook their own biases, and draw on this cache of knowledge, perhaps they will be able to better assist families in selecting and accessing postsecondary opportunities that are the best fit for their child and family.

Primary language support. Use of the primary language during instruction with CLD students plays a significant role in their acquisition of knowledge and skills (Cline \& Necochea, 2003; Klingner \& Vaughn, 2000). Concepts that students learn in their primary language (i.e., conceptual knowledge, cognitive processing skills, problem solving skills) can be accessed and utilized in English once the corresponding English vocabulary is learned (Cummins, 1996). By utilizing the student's primary language, educators are capitalizing on the previous learning and life experiences students bring to the classroom. New or difficult concepts could be introduced or previewed in the primary language to build students' background and prepare them for instruction in English (Freeman \& Freeman, 2000). Moreover, if educators take the time to build vocabulary in a student's primary language, they can make connections to build language skills in English.

Similar to Sanford et al. (2012), we believe that support in the primary language can be as simple as labeling a picture in the student's native language to more robust efforts such as providing a preview of an English lesson in the student's native language. However, we also recognize that not all special educators have the ability to speak multiple languages and CLD students with moderate or severe ID can demonstrate unique language needs 
(e.g., non-verbal, stuttering, difficulty with interpreting receptive language). In any case, special educators should seek what students know in their native language and how they can build upon that knowledge in the second language by making connections to identical or similar skills, resulting in cross-linguistic transfer (Cummins, 1981). Furthermore, special educators should feel comfortable seeking assistance from their administrators, English as Second Language teachers within the school, and even a student's family members to better assist them with providing such support. All students, despite their language ability, should be provided with the necessary supports needed to be successful in their classrooms and we urge special educators to advocate for these students based on family suggestions and support (Good, Masewicz, \& Vogel, 2010).

In alignment with the SDAIE and PLUSS models, our framework continues to stress the need for students to engage in learning that connects prior knowledge and extends learning through generalization of language. Rivera, Mason, Moser, and Ahlgrim-Delzell (2014) conducted a study that involved teaching the same new vocabulary, in Spanish and English, to a CLD student with moderate or severe ID. An alternating treatments design was used to compare the effects of Spanish and English language of instruction. Results from the study demonstrated that the student was able to acquire Spanish vocabulary at a faster rate; however, over a short amount of time he was able to acquire the same number of English vocabulary. This suggests that, like typically developing CLD students, primary language serves as a tool to reinforce extensions of ideas and concepts. Supporting CLD students with moderate or severe ID through the use of their native language may provide better access to academic content that can, in turn, better prepare students to take advantage of postsecondary opportunities. While research is lacking in this area for this specific population, other researchers have noted that allowing typically developing CLD students to engage in native language discussions with others gives them opportunities to acquire and express knowledge at higher levels of cognitive rigor as well as clarifying any misunderstandings (Klingner, Boardman, Eppolito, \& Schonewise, 2012).

Multiple opportunities to respond. CLD students with moderate or severe ID bring a wide-range of academic, cognitive, and linguistic strengths and needs to the classroom. Teachers should be aware of students' strengths and needs in order to provide multiple points of entry to lesson content. Similar to UDL's representation concept, instruction should be designed to allow students to interact with main points, ideas, concepts, and vocabulary in multiple ways (Cline \& Necochea, 2003). Teachers can present, for example, concepts of alphabet knowledge through the use of multiple supports such as realia (authentic manipulatives or sources of information), visuals, and primary language use. Allowing CLD students with moderate or severe ID multiple opportunities to interact as well as respond to various tasks can increase the likelihood of acquisition of content skills and may also aid with increased language proficiency skills. Increasing opportunities to respond to skills taught is important for this population especially if progress towards a goal becomes stagnant (Browder et al., 2014). For example, strategies like response cards have been shown to increase opportunities to respond and have demonstrated success for students with ID (Skibo, Mims, \& Spooner, 2011). Determining a student's response modes is also of importance and should be taken into consideration 
when teaching any skill. Whether the student uses speech or some other means of communication, technologies can assist in facilitating students' participation in lessons to the fullest extent possible.

Technology. Researchers have demonstrated that the use of technology can be beneficial for teaching a variety of academic skills such as literacy to CLD students with ID (Silverman \& Hines, 2009; Rivera et al., 2012; Rivera et al., 2014). Technology is a malleable tool that can be adapted to meet the linguistic, academic, and functional needs of varying students. Mobile devices such as iPads ${ }^{\circledR}$ are highly customizable (e.g., auditory output, touch screen capabilities, virtual assistive features, internet access, dictionary), engaging, and lend themselves to portability that translates to easy access across a variety of locations (Kagohara et al., 2013). It is this mobility and access that makes technology so advantageous. For instance, using a talking photo album, Cooke, Mackiewicz, Wood, and Helf (2009) taught mothers with limited English proficiency to teach English vocabulary to their pre-kindergarten children. The researchers provided mothers with a simple device that allowed them to insert photographs and record the names of the photographs in Spanish and English. With the use of a Spanish interpreter, mothers were trained how to use the technology to tutor their children. Through the use of parental, primary language, and technology support, results indicated that English vocabulary gains were made across both students and mothers.

The infusion of technology allows for the presentation of information in multimedia formats that can allow a learner to engage with an array of visual and verbal stimuli, which can lead to an increase in acquired knowledge (Mayer, 2005). Rivera et al. (2012; 2014) and Spooner, Kemp-Inman, Ahlgrim-Delzell, Wood, and Davis (2015) demonstrated this concept by using a multimedia, shared story presentation on a laptop and $\mathrm{iPad} \circledast$, respectively, to teach literacy skills to CLD students with moderate or severe ID with success. Additional forms of technology have also been shown successful with CLD students with moderate or severe ID. For example, speech-generating devices were shown to increase peer interactions for an ESL student with ID in an inclusive classroom (Chung \& Carter, 2013). Other low-tech strategies can also be implemented and should be considered for CLD students with moderate or severe ID. For example, visual supports such as visual activity schedules have been identified as an evidence-based practice for students with ID (Spriggs, Mims, van Dijk, \& Knight, 2016). Similarly, graphic organizers have long been used as a strategy to promote understanding of concepts for students with a wide range of ability levels, including CLD students (Sandefur, Watson, \& Johnston, 2007) and students with moderate or severe ID (Knight, Spooner, Browder, Smith, \& Wood, 2013). Through the incorporation of the components of the proposed framework, technology (e.g., multimedia content, translation software, mobile devices, assistive technology) can serve as a base to develop multifaceted instruction that can aid in the academic success of this population.

Self-determination. There has been a long history of the well-documented need for all students with ID to gain independence through self-determined learning (Wehmeyer, Shogren, Palmer, Williams-Deihm, Little, \& Boulton, 2012). Student directed learning strategies should be embedded within the learning environment to allow CLD students 
with moderate or severe ID to support their own learning, rather than always being told "what" and "how" to learn. Wehmeyer, Palmer, Agran, Mithaug, and Martin (2000) created the self-determined learning model of instruction to teach students how to set goals, take action, and adjust their plans. Through this model students are taught to identify problems, solutions, barriers, and consequences for these solutions. Studies have shown that students with moderate or severe ID can use such skills to access the general curriculum and increase their performance on academic, transition, and selfdetermination goals (Agran, Cavin, Wehmeyer, \& Palmer, 2006; Shogren, Palmer, Wehmeyer, Williams-Diehm, \& Little, 2012).

In spite of the value that self-determination has in mainstream culture and its' evidence for improving academic and transition outcomes, it is not entirely clear how selfdetermination interventions meet the needs of CLD students with disabilities and their families (Trainor, Lindstrom, Simon-Burroughs, Martin \& McCray Sorrells, 2008). Culture is ambiguous and is affected by race, socioeconomic status, disability, gender, and shared experiences, which may lead to additional inclusion of other sub-cultures. There are multiple factors that need to be taken into consideration when determining how to promote self-determination skills for CLD students with disabilities. In a review of literature, Shogren et al. (2012) identified 10 articles that examined the relationship between CLD students with disabilities and self-determination. Through their work, the authors identified four themes across the literature that should be taken into consideration when teaching self-determination skills to CLD students with disabilities. First, selfdetermination behaviors look different across cultures. Shogren et al. argued that each family has distinct principles and that flexibility is warranted when trying to understand what may work best for CLD families. Second, self-determination interventions should be more culturally appropriate, that is, adapted to align with values that are not typically embraced by the mainstream (e.g., living independently). Third, plans for selfdetermination must include the opinions of CLD families to make certain the values and appropriateness of the skills reflect the cultural identity of the family and student. Finally, for the implementation of self-determination skills to be successful, families need to be educated on the benefits of their child learning such skills and teachers need to be trained how to create safe environments that are culturally responsive and respect the values of CLD families.

\section{Moving Beyond the Classroom}

The application of the proposed framework seeks to provide a culturally responsive base of strategies that support CLD students with moderate or severe ID in all facets of their education. By creating appropriate supports, meaningful access to the general curriculum is possible. This access can also lead to increased involvement and preparedness for post school outcomes. In a systematic review of the literature, Test et al. (2009) identified 16 predictors of improved post school outcomes for students with disabilities. Some of these predictors included inclusion in general education, student support, development of independent living skills, community experiences, self- determination skills, and parental involvement. In other words, appropriate academic and functional skills instruction can equate to improved postsecondary opportunities (Kearns et al., 2010). 
Table 1

Definition and Research Examples for Framework Components

Component Universal Design for Learning

\begin{tabular}{ll} 
Safe Environment & A safe and stress free environment in which a \\
student's culture is respected. A safe environment is \\
one in which students feel free to take risks because \\
the environment is characterized by low anxiety \\
among students and fosters motivation, self- \\
confidence and self-advocacy. \\
\hline Instruction that assures a consistent pattern of \\
instructional trials that incorporates an antecedent, \\
behavior, and consequence. The consistency of these \\
instructional trials may be implemented by various \\
individuals and can include operationalized \\
procedures (e.g., prompts needed, schedule for fading \\
prompts, feedback for correct and incorrect \\
responses).
\end{tabular}

\section{Definition}

A set of principles for curriculum development that focus on the what of learning, how of learning, and why of learning designed to assure all students have equal opportunities to learn (National Center on Universal Design for Learning, 2014)

\section{Research Examples}

Courey, Tappe, Siker, \& LePage, 2013

Meyer \& Rose, 2000

Spooner, Baker, Harris, Ahlgrim-Delzell, \& Browder, 2007

Schinke-Llano \& Vicars, 1993

Cline \& Necochea, 2003

Callicott, 2003 Browder, Wood, Thompson, \& Ribuffo, 2014

Greer, Chavez-Brown, Nirgudkar, Stolfi, \& Rivera-Valdes, 2005

Hicks, Bethune, Wood, Cooke, \& Mims, 2011

Lopes-Murphy, 2012

Integrating Cultural
Information
Creating person-based instruction and lessons based on each individual's cultural heritage/socio-cultural background.
Haneda \& Wells, 2012

Moll, Amanti, Neff \& González, 1992

Rios-Aguilar \& Kiyama, 2012 


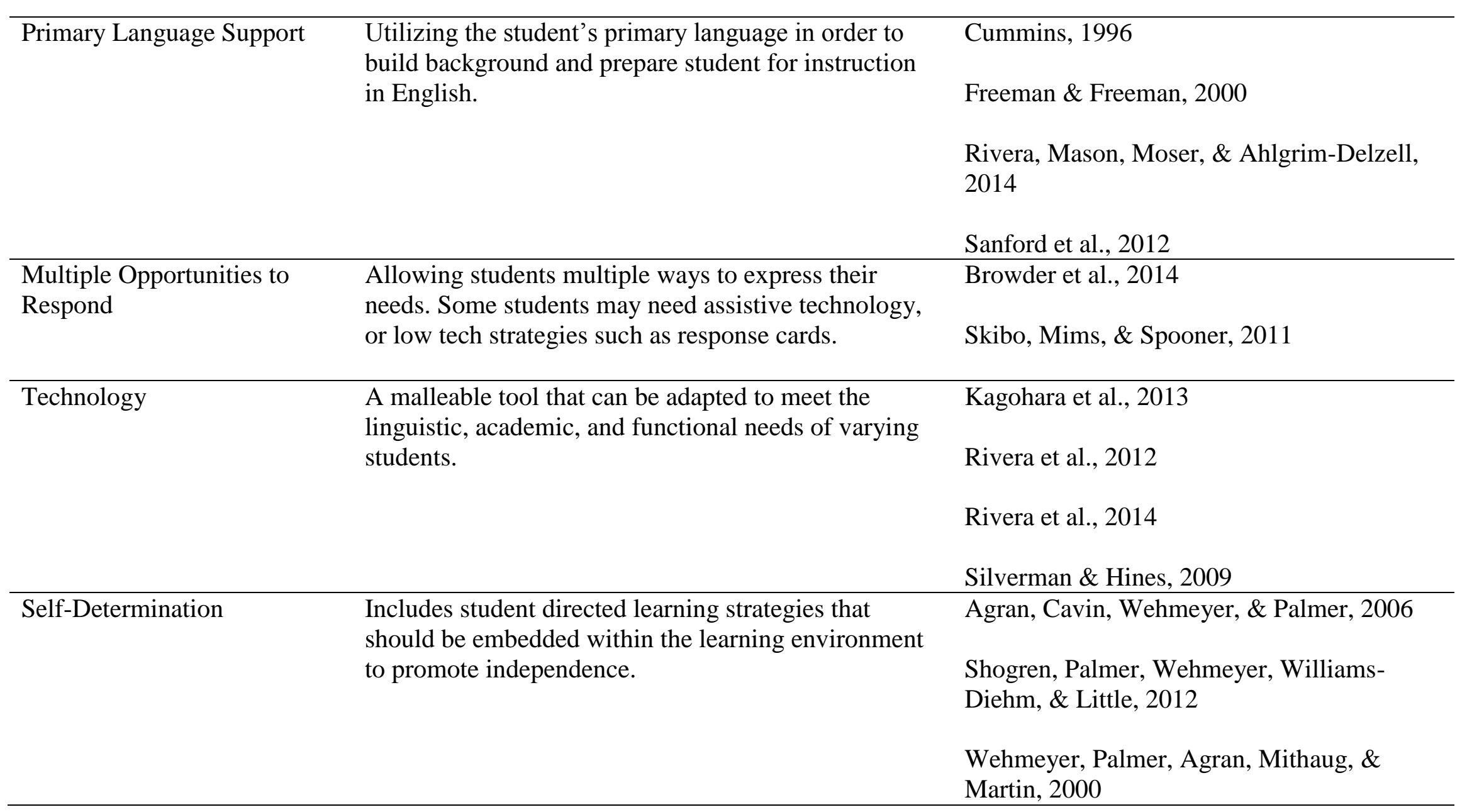


Our framework may contribute to improved academic outcomes and includes many of the predictors identified by Test et al. (2009). While we have identified guidelines for enhanced instruction, as Turnbull et al. (2003) indicated, the importance of preparing students for independent living and employment cannot be understated. To uphold the mandates provided by IDEA and ensure an enhanced quality of life for CLD students with moderate or severe ID there is a need for parental or guardian support, participation in educational decisions, and general buy-in; especially when considering students' lives after high school.

Most of the discussion thus far has been centered on academic guidelines for CLD students with moderate or severe ID. For continued success within and outside of the classroom, family input on educational decisions is needed. Participation in IEP planning can be difficult for many families who have children with exceptionalities; however, the establishment of communication and mutual partnerships within these meetings seems more problematic for CLD families (e.g., Griffin, 2011; Jung, 2011). Compared to mainstream cultures that highly value independence and self-determination, as previously mentioned, educators might find themselves at odds with the cultural beliefs of CLD families who may instead value family contributions and a team vs. I approach (Kim \& Morningstar, 2005; Turnbull, Turnbull, Ewrin, Soodak, \& Shogren, 2015). Because of varying cultural beliefs, educators should approach postsecondary education opportunities in ways that not only affect the student but the family as well.

CLD families should be given the chance to freely discuss the options that are available and how these options can benefit the family and child, thus leading to more positive outcomes (Pleet, 2000). Kim and Morningstar (2005) identified four concerns that CLD families have during IEP and transition planning: (a) professional attitudes, (b) diversity concerns, (c) contextual barriers, and (c) bureaucratic barriers. The researchers noted that lack of communication could lead to mistrust and feelings of isolation. Discrimination and holding false pretenses of CLD families can lead to feelings of disrespect. A lack of services, such as translators, can negatively influence transition planning. Socioeconomic status and a lack of information about the possibilities of transitional resources can be discouraging for CLD families and their child and can stifle meaningful progress. As a result, educators need to be sensitive to the needs of these families and ensure their successful inclusion within the IEP team. It is imperative to respect the cultural values of all families, allow them to lead meetings, and provide equality in decision making.

To further increase post school opportunities, such as placement in postsecondary programs, educators must connect CLD families and students with moderate or severe ID to appropriate local adult service agencies (Trainor, 2008). Access to both general and vocational curricula can lead to increased skill sets that are needed not only for employment purposes but also for smooth transitions into postsecondary education programs. Adult service agencies can provide assistance to CLD families and their children; however, school personnel should seek to educate families on how to access these services and provide the needed documentation to ensure services are rendered. As discussed by Schuster, Ciulla Timmons, and Moloney (2003), many parents can be overwhelmed with the process of seeking appropriate services that support their child. Cultural sensitivity, family involvement in transition planning, and access to the general curriculum and appropriate service agencies can aid in the successful transition into postsecondary education programs for CLD students with ID. According to Grigal et al. (2013), students with ID who enroll in postsecondary education programs, if provided with the appropriate supports, can be 
successful in academic classes, have the opportunity to develop new job skills, and can be part of a larger community that in return may build connections for improved employment. With the continued growth of postsecondary educational opportunities and the needed accommodations, CLD students with moderate or severe ID can be successful.

\section{Conclusion}

The variables presented as part of our proposed framework are a collection of strategies that are research based and exist within other models of education for CLD students or students with moderate or severe ID. To date, we have not identified any educational frameworks that support CLD students with moderate or severe ID throughout their education. The strategies selected for this framework hold promise in augmenting the education of this population and should not be misconstrued as a model to replace current educational practices. The framework seeks to include sound instructional strategies that are based in behavioral, linguistic, and instructional theory, while also being culturally responsive to the diverse needs of CLD students with moderate or severe ID. Future research is needed to determine the efficacy of this model and its implications for students and practitioners. Furthermore, researchers need to investigate how to properly support monolingual teachers with the tools to educate CLD students with moderate or severe ID, how to strengthen collaborative efforts with ESL and special educators, and determine ways to ensure proper access to the general curriculum in a variety of instructional settings for these students. By utilizing best practices infused with culturally responsive techniques, researchers and practitioners can enhance academic outcomes, which in turn can lead to improved postsecondary outcomes.

The lack of guidelines for educating CLD students with moderate or severe ID (Mueller et al., 2006) and the fact that students with moderate or severe ID in general are the least likely to exit school with a job or a high school diploma (Wagner, Newman, Cameto, Levine, \& Garza, 2006) is concerning. Coupled with the graduation data surrounding students with disabilities as well as CLD students, pro-active strategies must be taken to develop learning environments in which all students gain access to the content and social experiences school can offer. Kearns et al. (2010) indicated that successful life outcomes for students with moderate or severe ID have primarily emphasized employment; however, that is no longer the case - "college and postsecondary education opportunities for these students are ever increasing" (p. 9). The concept of college and career readiness was forefront in the development of the Common Core State Standards (CCSSO, 2010) and continues to guide instruction for all students, including those who are CLD and/or have moderate or severe ID. Kearns et al. (2010) suggested that educators hold great value for college and career ready standards, finding connectedness to the specific needs of students with moderate or severe ID (e.g., student independence, literacy, communication). The academic culturally responsive framework proposed in this paper for CLD students with moderate or severe ID parallels the college and career ready standards with continued focus on the need to build student communication, self-determination, and personal relevance within the curriculum taught.

Successful adult employment for this population has been associated with student, family, and school factors (Carter, Austin, \& Trainor, 2012). For CLD students with moderate or severe ID, these factors may exist with even greater robustness. In order to continue to build environments 
and communities that celebrate diversity, yet support access, educators and researchers must respond to the unique and salient needs of students with CLD and moderate or severe ID by using research and evidence-based practices in education, special education, and the education of culturally and linguistically diverse students.

\section{References}

Agran, M., Cavin, M., Wehmeyer, M., \& Palmer, S. (2006). Participation of students with moderate to severe disabilities in the general curriculum: The effects of the selfdetermined learning model of instruction. Research and Practice for Persons with Severe Disabilities, 31(3), 230-241. https://doi.org/10.1177/154079690603100303

Architectural Barriers Act of 1968, P.L. 90-480, 42 U.S.C. 4151 et seq.

August, D., \& Shanahan T. (2006). Developing literacy in second-language learners: Report of the national literacy panel on language-minority children and youth. Mahwah, NJ: Lawrence Erlbaum.

Banks, T., Sapp, M., \& Obiakor, F. E. (2013). Understanding BF Skinner: Building emotional competence in students with diverse learning needs. Multicultural Learning and Teaching, 9, 53-66. https://doi.org/10.1515/mlt-2013-0021

Browder, D. M., Wood, L., Thompson, J., \& Ribuffo, C. (2014). Evidence-based practices for students with severe disabilities (Document No. IC-3). Retrieved from University of Florida, Collaboration for Effective Educator, Development, Accountability, and Reform Center website: http://ceedar.education.ufl.edu/tools/innovation-configurations/

Bureau of Labor Statistics, U.S. Department of Labor. (2013). News release: Persons with a disability: Labor force characteristics - 2013. http://www.bls.gov/news.release/pdf/disabl.pdf

Calaff, K. P. (2008). Supportive schooling practices that support culturally and linguistically diverse students' preparation for college. NASSP Bulletin, 92(2), 95-110. https://doi.org/10.1177/0192636508321196

Calderon, M. (2007). Teaching reading to English language learners, grades 6-12: A framework for improving achievement in the content areas. Thousand Oaks, CA: Corwin Press.

Callicott, K. J. (2003). Culturally sensitive collaboration within person-centered planning. Focus on Autism \& Other Developmental Disabilities, 18(1), 60-68. https://doi.org/10.1177/108835760301800108

Carter, E. W., Austin, D., \& Trainor, A. A. (2012). Predictors of post school employment outcomes for young adults with severe disabilities. Journal of Disability Policy Studies, 23(1), 50-63. https://doi.org/10.1177/1044207311414680 
Physical Disabilities: Education and Related Services, 35(2), 23-48

Cartledge, G., \& Kourea, L. (2008). Culturally responsive classrooms for culturally diverse students with and at risk for disabilities. Exceptional Children, 74, 351-371.

Center for Applied Special Technology [CAST]. (2011). Universal Design for Learning Guidelines version 2.0. Wakefield, MA: Author.

Chung, Y., \& Carter, E. W. (2013). Promoting peer interactions in inclusive classrooms for students who use speech-generating devices. Research and Practice for Persons with Severe Disabilities, 38(2), 94-109. https://doi.org/10.2511/027494813807714492

Cline, Z., \& Necochea, J. (2003). Specially designed academic instruction in English (SDAIE): More than just good instruction. Multicultural Perspectives, 5, 18-24. https://doi.org/10.1207/S15327892MCP0501_4

Cooke, N. L., Mackiewicz, S. M., Wood, C. L., \& Helf, S. (2009). The use of audio prompting to assist mothers with limited English proficiency in tutoring their pre-kindergarten children on English vocabulary. Education and Treatment of Children, 32(2), 213-229. https://doi.org/10.1353/etc.0.0057

Cooper, J. O., Heron, T. E., \& Heward, W. L. (2007). Applied behavior analysis (2 ${ }^{\text {nd }}$ ed.). Upper Saddle River, NJ: Pearson.

Courey, S. J., Tappe, P., Siker, J., \& LePage, P. (2013). Improved lesson planning with universal design for learning (UDL). Teacher Education and Special Education, 36(1), 7-27. https://doi.org/10.1177/0888406412446178

Coyne, P., Pisha, B., Dalton, B., Zeph, L. A., \& Smith, N. C. (2012). Literacy by design: A universal design for learning approach for students with significant intellectual disabilities. Remedial and Special Education, 33(3), 162-172. https://doi.org/10.1177/0741932510381651

Crawford, A. N. (2005). Communicative approaches to second language acquisition: From oral language development into the core curriculum and L2 literacy. In C. F. Leyba (Ed.), Schooling and Language Minority Students: A Theoretical-Practical Framework (3rd ed., pp. 3-32). Los Angeles, CA: LBD.

Cummins, J. (1981). The role of primary language development in promoting educational success for language minority students. In C. F. Leyba (Ed.), Schooling and language minority students: A theoretical framework (pp. 3-49). Los Angeles:

Evaluation, Dissemination and Assessment Center, CSULA.

Cummins. J. (1996). Negotiating identities: Education for empowerment in a diverse society. Ontario, Canada: California Association for Bilingual Education.

Downing, J. E., \& MacFarland, S. (2010). Education and individuals with severe disabilities: Promising practices. Retrieved from 
http://cirrie.buffalo.edu/encyclopedia/pdf/en/severe_disabilities_education_and_individua ls_with_severe_disabilities_promising_practices.pdf

Engelmann, S., \& Carnine, D. (1991). Theory of instruction: Principles and applications. Eugene, OR: ADI Press.

Fry, R. (2008). The role of schools in the English language learner achievement gap. Retrieved from http://files.eric.ed.gov/fulltext/ED502050.pdf

Freeman, D., \& Freeman, Y. (2000). Meeting the needs of English language learners. National Council for Teachers of English: Maintaining Languages, 12(1), 1-7.

Gersten, R., \& Baker, S. (2000). What we know about effective instructional practices for English language learners. Exceptional Children, 66, 454-470.

Gonzalez, R., Pagan, M., Wendell, L., \& Love, C. (2011). Supporting ELL/culturally and linguistically diverse students for academic achievement. Retrieved from https://www.brown.edu/academics/education-alliance/teaching-diverselearners/sites/brown.edu.academics.education-alliance.teaching-diverselearners/files/uploads/ELL\%20Strategies\%20Kit_Intl\%20Ctr\%20for\%20Leadership\%20i n\%20Educ\%202011.pdf

Good, M. E., Masewicz, S., \& Vogel, L. (2010). Latino English language learners: Bridging achievement and cultural gaps between schools and families. Journal of Latinos in Education, 9, 321-339. http://dx.doi.org/10.1080/15348431.2010.491048

Greer, R. D., Chavez-Brown, M., Nirgudkar, A. S., Stolfi, L., \& Rivera-Valdes, C. (2005). Acquisition of fluent listener responses and the educational advancement of young children with autism and severe language delays. European Journal of Behavior Analysis, 6(2), 1-25.

Griffin, M. M. (2011). Promoting IEP participation: Effects of interventions, considerations for CLD students. Career Development for Exceptional Individuals, 34, 153-164. https://doi.org/10.1177/0885728811410561

Griffiths, D. M., Owen, F., Gosse, L., Stoner, K., Tardif, C. Y., Watson, S., ...Vyrostko, B. (2003). Human rights and persons with intellectual disabilities: An action-research approach for community-based organizational self-evaluation. Journal of Developmental Disabilities, 10, 25-42.

Grigal, M., Hart, D., \& Weir, C. (2013). Postsecondary education for people with intellectual disability: Current issues and critical challenges. Inclusion, 1(1), 50-63. https://doi.org/10.1352/2326-6988-1.1.050

Haager, D., \& Klingner, J. K. (2005). Differentiating instruction in inclusive classrooms: The special educator's guide. Boston, MA: Pearson. 
Physical Disabilities: Education and Related Services, 35(2), 23-48

Haneda, M., \& Wells, G. (2012). Some key pedagogic principles for helping ELLs to succeed in school. Theory into Practice, 51, 297-304. http://dx.doi.org/10.1080/00405841.2012.726059

Herrera, S. \& Murry, K. (2011). Mastering ESL and bilingual methods: Differentiated instruction for culturally and linguistically diverse (CLD) students. Boston, MA: Allyn and Bacon.

Hicks, S. C., Bethune, K. S., Wood, C. L., Cooke, N. L., \& Mims, P. J. (2011). Effects of Direct Instruction on the acquisition of prepositions by students with intellectual disabilities. Journal of Applied Behavior Analysis, 44(3), 675-679. https://doi.org/10.1901/jaba.2011.44-675

Horner-Johnson, W., \& Drum, C. E. (2006). Prevalence of maltreatment of people with intellectual disabilities: A review of the recently published research. Mental Retardation and Developmental Disabilities Research Reviews, 12, 57-69. https://doi.org/10.1002/mrdd.20097

IDEA Section 618 Data Products: Static Tables (2016). Retrieved from http://www2.ed.gov/programs/osepidea/618-data/static-tables/index.html

Individuals with Disabilities Education Act of 1997, 20 U.S.C. 1400 et seq.

Jung, A. W. (2011). Individualized education programs (IEPs) and barriers for parents from culturally and linguistically diverse backgrounds. Multicultural Education, 18(3), 21-25.

Kagohara, D. M., van der Meer, L., Ramdoss, S., O’Reilly, M. F., Lancioni, G. E., Davis, T. N., ... \& Sigafoos, J. (2013). Using iPods $₫$ and iPads $®$ in teaching programs for individuals with developmental disabilities: A systematic review. Research in Developmental Disabilities, 34(1), 147-156. https://doi.org/10.1016/j.ridd.2012.07.027

Kearns, J., Kleinert, H., Harrison, B., Sheppard-Jones, K., Hall, M., \& Jones, M. (2010). What does 'college and career ready' mean for students with significant cognitive disabilities? Lexington: University of Kentucky.

Kim, K. H., \& Morningstar, M. E. (2005). Transition planning involving culturally and linguistically diverse families. Career Development for Exceptional Individuals, 28(2), 92-103. https://doi.org/10.1177/08857288050280020601

Klingner, J. K., Boardman, A. G., Eppolito, A. M., \& Schonewise, E. A. (2012). Supporting adolescent English language learners' reading in the content areas. Learning Disabilities: A Contemporary Journal, 10(1), 35-64.

Klingner, J. K., \& Vaughn, S. (2000). The helping behaviors of fifth graders while using collaborative strategic reading (CSR) during ESL content classes. TESOL Quarterly, 34, 69-98. https://doi.org/10.2307/3588097 
Knight, V. F., Spooner, F., Browder, D. M., Smith, B. R., \& Wood, C. L. (2013). Using systematic instruction and graphic organizers to teach science concepts to students with autism spectrum disorders and intellectual disability. Focus on Autism and Other Developmental Disabilities, 28(2), 115-126. http://dx.doi.org/10.1177/1088357612475301

Krashen, S. D. (1982). Principles and practice in second language acquisition. New York, NY: Pergamon Press.

Linan-Thompson, S., \& Vaughn, S. (2007). Research-based methods of reading instruction for English language learners, Grades K-4. Alexandria, VA: ASCD.

Lopes-Murphy, S.A. (2012). Universal Design for Learning: Preparing secondary education teachers in training to increase academic accessibility of high school English learners. The Clearing House: A Journal of Educational Strategies, Issues, and Ideas for Middle \& High School Teachers, 85(6), 226-230. https://doi.org/10.1080/00098655.2012.693549

Mayer, R. E. (2005). The Cambridge handbook of multimedia learning. New York, NY: Cambridge University Press. https://doi.org/10.1017/CBO9780511816819

Meyer, A., \& Rose, D. (2000). Universal design for individual differences. Educational Leadership, 58, 39-43.

Migliore, A., \& Butterworth, J. (2008). Trends in outcomes of the vocational rehabilitation program for adults with developmental disabilities: 1995-2005. Rehabilitation Counseling Bulletin, 52, 35-44. https://doi.org/10.1177/0034355208320075

Miner, C. A., \& Bates, P. E. (1997). The effect of person centered planning activities on the IEP/transition planning process. Education and Training in Mental Retardation and Developmental Disabilities, 32, 105-112.

Moll, L. C., Amanti, C., Neff, D., \& González, N. (1992). Funds of knowledge for teaching: Using a qualitative approach to connect homes and classrooms. Theory into Practice, 31, 132-141. https://doi.org/10.1080/00405849209543534

Mueller, T. G., Milian, M., \& Lopez, M. I. (2009). Latina mothers' views of a parent-to-parent support group in the special education system. Research and Practice for Persons with Severe Disabilities, 34(3-4), 113-122. https://doi.org/10.2511/rpsd.34.3-4.113

Mueller, T. G., Singer, G. H. S., \& Carranza, F. D. (2006). A national survey of the educational planning and language instruction for students with moderate to severe disabilities who are English language learners. Research and Practice for Persons with Severe Disabilities, 31, 242-254. https://doi.org/10.1177/154079690603100304 
Physical Disabilities: Education and Related Services, 35(2), 23-48

National Center for Education Statistics (2015). Common core of data. Retrieved from https://nces.ed.gov/ccd/tables/ACGR_RE_and_characteristics_2013-14.asp

Newman, L., Wagner, M., Cameto, R., \& Knokey, A. M. (2009). The post-high school outcomes of youth with disabilities up to 4 years after high school: A report from the national longitudinal transition study-2 (NLTS2) (NCSER 2009-3017). Menlo Park, CA: SRI International.

Ovando, C. J., \& Combs, M. C. (2012). Bilingual and ESL classrooms (5 ${ }^{\text {th }}$ ed.). Boston, MA: McGraw-Hill.

Park, S., Magee, J., Martinez, M. I., Willner, L., \& Paul, J. (2016). English language learners with disabilities: A call for additional research and policy guidelines. Retrieved from http://www.ccsso.org/Documents/ELSWD-

A\%20Call\%20for\%20Additional\%20Research\%20and\%20Policy\%20Guidance080216.pdf

Paneque, O. M., \& Barbetta, P. M. (2006). A study of teacher efficacy of special education teachers of English language learners with disabilities. Bilingual Research Journal, 30, 171-193. https://doi.org/10.1080/15235882.2006.10162871

Pennington, R., Courtade, G., Ault, M., \& Delano, M. (2016). Five essential features of quality educational programs for students with moderate and severe intellectual disability: A guide for administrators. Education and Training in Autism and Developmental Disabilities, 51, 294-306.

Peske, H. G., \& Haycock, K. (2006). Teaching inequality: How poor and minority students are shortchanged on teacher quality. Retrieved from http://files.eric.ed.gov/fulltext/ED494820.pdf

Pleet, A. (2000). Investigating the relationship between parent involvement in transition planning and post-school outcomes for students with disabilities. Michigan: UMI Dissertation Services.

Restrepo, M. A., Morgan. G. P., \& Thompson, M. S. (2013). The efficacy of a vocabulary intervention for dual language learners with language impairment. Journal of Speech, Language, and Hearing Research, 56, 748-765. https://doi.org/10.1044/1092$\underline{4388(2012 / 11-0173)}$

Rios-Aguilar, C., \& Kiyama, J. M. (2012). Funds of knowledge: An approach to studying Latina(o) students' transition to college. Journal of Latinos and Education, 11(1), 2-16. https://doi.org/10.1080/15348431.2012.631430 
Rivera, C. J., Mason, L., Moser, J., \& Ahlgrim-Delzell, L. (2014). The effects of an iPad® multimedia shared story intervention on vocabulary acquisition for an English language learner. Journal of Special Education Technology, 29(4), 32-48. https://doi.org/10.1177/016264341402900403

Rivera, C. J., Wood, C. L., \& Spooner, F. (2012). Comparative effects of Spanish and English instruction for English language learners with moderate intellectual disability. Multiple Voices for Ethnically Diverse Exceptional Learners, 13, 42-55.

Sandefur, S. J., Watson, S. W., \& Johnston, L. B. (2007). Literacy development, science curriculum, and the adolescent English language learner: Modifying instruction for the English-only classroom. Multicultural Education, 14(3), 41-50.

Sanford, A. K., Brown, J. E., \& Turner, M. (2012). Enhancing instruction for English learners in response to intervention systems: The PLUSS model. Multiple Voices for Ethnically Diverse Exceptional Learners, 13(1), 56-70.

Schinke-Llano, L., \& Vicars, R. (1993). The affective filter and negotiated interaction: Do our language activities provide for both? The Modern Language Journal, 77(3), 325-329. https://doi.org/10.1111/j.1540-4781.1993.tb01979.x

Schuster, J. L., Ciulla Timmons, J., \& Moloney, M. (2003). Barriers to successful transition for young adults who receive SSI and their families. Career Development for Exceptional Individuals, 26(1), 47-66. https://doi.org/10.1177/088572880302600104

Shogren, K., Palmer, S., Wehmeyer, M. L., Williams-Diehm, K., \& Little, T. (2012). Effect of intervention with the Self-Determined Learning Model of Instruction on access and goal attainment. Remedial and Special Education, 33, 320-330. https://doi.org/10.1177/0741932511410072

Silverman, R., \& Hines, S. (2009). The effects of multimedia-enhanced instruction on the vocabulary of English-language learners and non-English-language learners in prekindergarten through second grade. Journal of Educational Psychology, 101, 305-314. https://doi.org/10.1037/a0014217

Siperstein, G. N., Parker, R. C., \& Drascher, M. (2013). National snapshot of adults with intellectual disabilities in the labor force. Journal of Vocational Rehabilitation, 39(3), 157-165.

Skibo, H., Mims, P. J., \& Spooner, F. (2011). Teaching number identification to students with significant cognitive disabilities using response cards. Education and Training in Developmental Disabilities, 46, 124-133.

Skinner, B. F. (1963). Operant behavior. American Psychologist, 18(8), 503-515. https://doi.org/10.1037/h0045185 
Physical Disabilities: Education and Related Services, 35(2), 23-48

Sobul, D. (1995). Specially designed academic instruction in English. (ERIC Document Reproduction Service No. ED391357). Retrieved from http://files.eric.ed.gov/fulltext/ED391357.pdf

Spooner, F., Baker, J. N., Harris, A. A., Ahlgrim-Delzell, L., \& Browder, D. M. (2007). Effects of training in universal design for learning on lesson plan development. Remedial and Special Education, 28(2), 108-116. https://doi.org/10.1177/07419325070280020101

Spooner, F., Kemp-Inman, A., Ahlgrim-Delzell, L., Wood, L., \& Davis, L. L. (2015). Generalization of literacy skills through portable technology for students with severe disabilities. Research and Practice for Persons with Severe Disabilities, 40(1), 52-70. https://doi.org/10.1177/1540796915586190

Spooner, F., Rivera, C. J., Browder, D. M., Baker, J. N., \& Salas, S. (2009). Teaching emergent literacy skills using culturally contextual story-based lessons. Research and Practice for Persons with Severe Disabilities, 34, 102-112. https://doi.org/10.2511/rpsd.34.3-4.102

Spriggs, A., Mims, P. J., Van Dijk, W., \& Knight, V. (2016). Activity schedules for individuals with intellectual disability: A review of the literature. Journal of Special Education, 1-13. http://dx.doi.org/10.1177/0022466916658483

Sullivan, A. L. (2011). Disproportionality in special education identification and placement of English language learners. Exceptional Children, 77, 317-334. https://doi.org/10.1177/001440291107700304

Test, D. W., Mazzotti, V. L., Mustain, A. L., Flower, C. H., Kortering, L., \& Kohler, P. (2009). Evidence-based secondary transition predictors for improving post school outcomes for students with disabilities. Career Development and Transition for Exceptional Individuals, 32, 160-181.

Trainor, A. A. (2008). Using cultural and social capital to improve postsecondary outcomes and expand transition models for youth with disabilities. The Journal of Special Education, 42(3), 148-162. https://doi.org/10.1177/0022466907313346

Trainor, A. A., Lindstrom, L., Simon-Burroughs, M., Martin, J. E., \& McCray Sorrels, A. (2008). From marginalized to maximized opportunities for diverse youth with disabilities. Career and Development for Exceptional Individuals, 31, 56-64. https://doi.org/10.1177/0885728807313777

Trainor, A. A., Murray, A., \& Kim, H. (2014). Postsecondary transition and English learners with disabilities: Data from the Second National Longitudinal Transition study. WCER Working Paper No. 2014-4. Wisconsin Center for Education Research.

Turnbull, A., Turnbull, R., Erwin, E. J., Soodak, L. C., \& Shogren, K. A. (2015). Families, Professionals, and Exceptionality ( $7^{\text {th }}$ ed.). Upper Saddle River, NJ: Pearson. 
Turnbull, H. R., Turnbull, A. P., Wehmeyer, M. L., \& Park, J. (2003). A quality of life framework for special education outcomes. Remedial and Special Education, 24(2), 6774. https://doi.org/10.1177/07419325030240020201

U.S. Department of Education. (2015). The biennial report to congress on the implementation of the title III state formula grant program. School years 2010-2012. Retrieved from http://www.ncela.us/files/uploads/3/Biennial_Report_1012.pdf

Wagner, M., Newman, L., Cameto, R., Levine, P., \& Garza, N. (2006). An overview of findings from wave 2 of the National Longitudinal Transition Study-2 (NLTS2). NCSER 20063004. National Center for Special Education Research.

Ward, T., \& Stewart, C. (2008). Putting human rights into practice with people with an intellectual disability. Journal of Developmental and Physical Disabilities, 20, 297-311. https://doi.org/10.1007/s10882-008-9098-4

Wehmeyer, M. L., Palmer, S. B., Agran, M., Mithaug, D. E., \& Martin, J. E. (2000). Promoting causal agency: The self-determined learning model of instruction. Exceptional Children, 66(4), 439-453.

Wehmeyer, M. L., Shogren, K. A., Palmer, S. B., Williams-Deihm, Little, T. D., \& Boulton, A. (2012). The impact of self-determined learning model of instruction on student selfdetermination. Exceptional Children, 78, 135-153.

Authors' note: Address correspondence concerning this article to Christopher Rivera at riverac@ecu.edu. 